\title{
KEBUTUHAN FASILITAS REKREASI DI KAWASAN TEPIAN SUNGAI CENRANAE PADDUPPA KOTA SENGKANG
}

\author{
Andi Yusri, Sherly Wunas, Ria Wikantari \\ Dosen Prodi Arsitektur, Fakultas Teknik Universitas Muhammadiyah Makassar \\ Dosen Magister Prodi Arsitektur Universitas Hasanuddin Makassar \\ Dosen Magister Prodi Arsitektur Universitas Hasanuddin Makassar \\ E-mail: yusri.andi76@gmail.com
}

\begin{abstract}
ABSTRAK
Mengingat potensi serta kecenderungan pertumbuhan fisik secara cepat sering terjadi di kawasan ini, namun belum diiringi dengan ketersediaan fasilitas rekreasi yang memadai dan menarik sehingga kawasan tersebut menjadi kurang produktif. Penelitian ini bertujuan untuk menjelaskan kebutuhan jenis fasilitas rekreasi, dan sarana prasarana pendukungnya berdasarkan karakteristik responden. Data diperoleh melalui survei lapangan dengan mewawancarai seratus responden yang terdiri dari pengunjung, pedagang kaki lima, dan masyarakat disekitar kawasan. Analisis secara deskriptif. Hasil penelitian menyimpulkan bahwa 1) kondisi permukaan air tergenang dengan elevasi mencapai 6 meter dipermukaan air dengan luas area genangan 14,32 km². Elevasi banjir besar mencapai 9 meter diatas muka air dengan luas genangan $195.00 \mathrm{~km}^{2}$. Kedalaman sungai 5 meter dalam kondisi normal. Ketersediaan fasilitas rekreasi belum. 2) Kebutuhan jenis fasilitas berdasarkan karakteristik responden mencakup ruang terbuka hijau publik (RTH Publik), ruang terbuka hijau privat (RTH Privat), fasilitas rekreasi, sarana pendukung, water catchment area, dan prasarana penunjang transportasi. 3) Arahan pengembangan adalah penambahan dan perbaikan fasilitas rekreasi baik dari segi kualitas dan kuantitasnya agar dapat meningkatkan ekonomi warga serta meningkatkan pendapatan asli daerah.
\end{abstract}

Kata Kunci : fasilitas rekreasi, karakteristik responden, kebutuhan fasilitas, sungai cenranae

\section{PENDAHULUAN}

Sejak ribuan tahun lalu fenomena perkembangan kota di berbagai tempat, suku bangsa akan selalu dipengaruhi oleh dinamika perkembangan masyarakatnya yaitu perkembangan kehidupan sosial, ekonomi, politik, pendidikan yang tercermin dalam perkembangan kotanya (Sujarto, 2001). Dinamika yang berkembang dalam masyarakat tumbuh dan berkembang secara alamiah, karena masyarakat yang hidup selalu ingin memenuhi hidupnya dan mengekspresikannya di dalam setiap perkembangannya. Disadari sepenuhnya bahwa volume pembangunan yang semakin meningkat seiring dengan meningkatnya jumlah penduduk suatu daerah. Pertumbuhan jumlah penduduk tersebut berimplikasi terhadap jumlah angkatan kerja. Saat ini peluang lapangan kerja sektor formal memerlukan persyaratan yang tidak mudah apalagi dengan tingkat pendidikan dan keterampilan yang serba terbatas. Pertumbuhan penduduk tersebut juga diiringi dengan pertumbuhan ekonomi yang tidak hanya terjadi pada sektor formal saja tetapi juga terjadi pada sektor informal khususnya Pedagang Kaki Lima. Istilah Pedagang Kaki
Lima pertama kali dikenal pada zaman Hindia Belanda, pada saat Gubernur Jenderal Stanford Raffles berkuasa. la menetapkan aturan yang mengharuskan Pedagang Kaki Lima membuat jarak sejauh 5 kaki atau sekitar 1,2 meter dari bangunan di pusat kota. Peraturan ini dilakukan untuk memberi ruang untuk jalur pejalan kaki sambil tetap memberikan kesempatan kepada Pedagang Kaki Lima yang berada 5 kaki dari bangunan. Formal inilah yang selanjutnya dikenal dengan "Kaki Lima" dan pedagang yang berjualan di tempat tersebut disebut "Pedagang Kaki Lima" atau "PKL". Pada awalnya PKL dianggap mengurangi estetika kota, keberadaan taman kota dan ruang publik dianggap kotor, ilegal dan memicu timbulnya kriminalitas.

Di Amerika Serikat muncul pandangan baru terhadap keberadaan PKL. Mulai tahun tersebut $\mathrm{PKL}$ disinyalir dapat meningkatkan jumlah pengunjung taman, membuat kawasan menjadi lebih hidup dan lebih menarik (Ginting, 2004). Menurut Yasin (2012), suatu kawasan dikatakan menarik apabila di dalam kawasan itu tercipta suasana kawasan yang nyaman, aman, produktif dan berkelanjutan sesuai dengan kebutuhan dan minat 
pengunjung sehingga mampu meningkatkan arus kunjungan dalam jumlah yang lebih besar. Keberadaan pengunjung sebelum, sesudah dan setelah berada dalam suatu kawasan wisata akan membentuk sebuah image akan hadirnya beberapa fasilitas yang cukup memadai sehingga kenangan dan pengalaman tersebut diharapkan mampu memberikan citra positif dengan tersedia serta ditampilkannya obyek secara menarik sehingga memberi nilai tambah. Ketersediaan fasilitas rekreasi merupakan ujung tombak dalam memberikan tourism service kepada pengunjung. Menurut Rahmawaty dkk (2006), bahwa karakteristik pengunjung tidak memberikan impact secara langsung terhadap perkembangan suatu kawasan namun perlu kita lihat keterkaitannya dengan persepsi pengunjung terhadap kebutuhan fasilitas yang dirumuskan melalui unsur suppy dan demand. Kedua unsur ini mewadahi berbagai fasilitas khususnya fasilitas dalam suatu kawasan wisata. Fasilitas berupa sarana dan prasarana wisata merupakan sumber daya alam dan sumber daya manusia yang mutlak dibutuhkan oleh pengunjung. Sarana dan prasarana yang dimaksud mencakup akomodasi, tempat makan dan minum, tempat belanja, fasilitas umum dalam kawasan wisata. Fasilitas umum yang dikaji adalah fasilitas yang biasanya tersedia ditempat wisata seperti tempat parkir, WC umum, plaza, ruang terbuka hijau dan lainnya, prasarana dasar untuk kegiatan wisata seperti jalan, sumber listrik dan energi, sumber air dan sistem pengairan, fasilitas kesehatan, sistem pembuangan kotoran/sanitasi, telekomunikasi, terminal angkutan, jembatan, dan sebagainya (Mirsa, 2011). Dengan semakin meningkatnya kebutuhan masyarakat akan rekreasi, maka diperlukan suatu usaha mencari terobosan-terobosan baru guna mengoptimalkan potensi yang ada. Potensi tersebut diyakini mampu memberikan dampak positif bagi peningkatan ekonomi masyarakat. Untuk itu perlu diketahui berbagai karakteristik pengunjung serta tingkat permintaan fasilitas rekreasi sehingga dapat meningkatkan daya tarik dari kawasan wisata tersebut. Banyak studi kasus dan penelitian yang terkait dengan permasalahan fasilitas dalam suatu kawasan rekreasi salah satunya adalah kawasan tepian Sungai Cenranae Padduppa yang berada di Kota
Sengkang. "Padduppa" dalam bahasa bugis berarti pertemuan, istilah "Padduppa" muncul dikarenakan daerah tersebut merupakan pertemuan dua sungai yakni Sungai Walannae dan Sungai Cenranae yang bermuara di Danau Tempe, sebuah tempat yang menyerupai pelataran di pesisir sungai yang dimanfaatkan sebagai kawasan kuliner oleh pemerintah daerah. Berdasarkan data kunjungan manca negara di kawasan danau tempe dan sekitarnya sebanyak 2560 pengunjung / tahun (Dinas Pemuda Olahraga Kebudayaan dan Pariwisata Kabupaten Wajo, 2013), hal ini didukung pula oleh target dan realisasi penerimaan pendapatan asli daerah (PAD) untuk tahun 2013 diatas 40 juta pertahun melebihi dari target yang direncanakan yakni 40 juta pertahun. Pemerintah daerah akan merencanakan untuk merelokasi seluruh warung PKL yang tersebar di penjuru Kota Sengkang untuk disatukan di kawasan ini. Penelitian ini bertujuan untuk menjelaskan kebutuhan jenis fasilitas rekreasi, dan sarana prasarana pendukungnya berdasarkan karakteristik responden.

\section{METODE \\ Rancangan Penelitian}

Penelitian ini dilakukan untuk menjelaskan kebutuhan jenis fasilitas rekreasi kawasan berdasarkan karakteristik responden. Metode yang digunakan adalah survei lapangan dengan mewawancarai 100 responden yang terdiri dari pengunjung, pedagang kaki lima, dan masyarakat disekitar kawasan. Data responden dianalisis secara deskriptif.

\section{Populasi dan Sampel}

Populasi dalam penelitian ini dibedakan atas pedagang kaki lima (5-feet street vendor), pengunjung, masyarakat di sekitar kawasan. Sampel penelitian terdiri dari PKL sandang-pangan/makanan-minuman, PKL campuran/pakaian bekas, pakaian baru, aksesoris, permainan). Pengunjung berdasarkan karakteristik sosial-ekonomi (jenis kelamin, usia, pendidikan, pekerjaan, dan pendapatan). Masyarakat di sekitar kawasan yakni, masyarakat yang memperoleh manfaat langsung akibat aktifitas yang terjadi disekitar kawasan dengan radius $50-100$ meter. Jumlah sampel sebanyak 100 responden. 


\section{Jenis dan Sumber Data}

Jenis data yang digunakan adalah data kualitatif dan data kuantitatif. Data kualitatif adalah data yang diperoleh dalam bentuk informasi baik secara lisan maupun tulisan. Data kuantitatif yakni data yang diperoleh dalam bentuk angka-angka yang dapat dihitung. Sumber data yang digunakan dalam penelitian ini adalah data primer dan sekunder. Data primer merupakan sumber data yang diperoleh secara langsung melalui penyebaran kuesioner dengan serangkaian pertanyaan secara terstruktur. Data sekunder merupakan data yang diperoleh melalui format laporan dan buku di instansi terkait.

\section{Metode Pengumpulan Data}

Pengumpulan data yang dilakukan melalui studi kepustakaan dan studi lapangan. Studi kepustakaan dengan mengkaji sumbersumber referensi baik melalui artikel, jurnal penelitian maupun sumber pustaka lainnya yang dapat mendukung hasil penelitian. Sedangkan studi lapangan dilakukan secara langsung ke lokasi penelitian dengan menyebarkan daftar angket atau kuesioner ke responden.

\section{Analisis Data}

Metode analisis yang digunakan berdasarkan rumusan masalah yang ada yakni analisa deskriptif, analisa delphi, dan analisa tabulasi silang. Analisa deskriptif menjelaskan tentang kondisi fisik lokasi dan ketersediaan jenis fasilitas rekreasi berdasarkan kondisi eksisting kawasan saat ini. Analisa delphi merupakan metode sistematis dalam mengumpulkan pendapat dari sekelompok responden melalui serangkaian kuesioner. Analisis tabulasi silang yakni teknik analisis dengan mengelaborasikan hasil observasi dan survei lapangan yang dilakukan sebagai fakta empiris.

\section{HASIL DAN PEMBAHASAN \\ Hasil \\ Kebutuhan Fasilitas Rekreasi Kawasan}

RTH Publik (Ruang Terbuka Hijau Publik), dari hasil survei responden memberi gambaran tentang jenis fasilitas rekreasi yang sesuai dengan kebutuhan responden menunjukkan jumlah pemilih RTH Taman Kota sebanyak 77 responden (77\%), Sarana Pendukung Area Parkir sebanyak 54 responden (54\%), Sarana Pendukung Bangku
Taman sebanyak 53 responden (53\%), Sarana Pendukung Toilet Umum sebanyak 49 responden (49\%), Fasilitas Rekreasi Permainan Anak 34 responden (34\%), Fasilitas Rekreasi Taman Air sebanyak 50 responden (50\%), Water Catchment Area Ruang Pemancingan 38 responden (38\%), Water Catchment Area Situ/danau sebanyak 20 responden (20\%). Berdasarkan tabel 1, 2, dan 3 dapat dijelaskan bahwa kebutuhan fasilitas rekreasi serta sarana prasarana pendukungnya terdiri dari; taman kota, tempat parkir, bangku taman, taman air, toilet umum, ruang pemancingan, jenis permainan anak, dan water catchment area. Karakteristik responden berdasarkan jenis kelamin, usia, dan tingkat pendidikan berpengaruh kuat terhadap kebutuhan fasilitas kawasan yang didominasi oleh kelompok responden masyarakat disekitar kawasan.

\section{Analisis Kebutuhan Fasilitas Rekreasi Kawasan}

RTH Publik Taman Kota, dari hasil survei diperoleh data berdasarkan karakteristik responden yang berpengaruh yakni jenis kelamin dan pekerjaan. Persentase berdasarkan jenis kelamin $80 \%$, terdiri dari jenis kelamin laki-laki yang memiliki persentase lebih dominan sebanyak 53 responden $(53 / 100 \times 100 \%=53 \%)$ dibandingkan dengan perempuan sebanyak 27 responden (27\%). Persentase berdasarkan jenis pekerjaan $72 \%$. Profesi pekerjaan yang lebih dominan adalah pedagang, sebanyak 32 responden (32\%). Sarana Pendukung Bangku taman, dari hasil analisis diperoleh data berdasarkan karakteristik responden yang berpengaruh yakni jenis kelamin, usia, dan pendapatan. Persentase berdasarkan jenis kelamin adalah $53 \%$ terdiri dari jenis kelamin laki-laki sebanyak 35 responden $(35 / 100 \times 100 \%=35 \%)$ dibandingkan dengan perempuan sebanyak 18 responden (18\%), persentase berdasarkan usia adalah $49 \%$. Usia rata-rata responden adalah 26-50 thn sebanyak 43 responden (43\%). Persentase berdasarkan tingkat pendapatan adalah $48 \%$. Tingkat pendapatan diatas 2 juta lebih signifikan dengan jumlah responden sebanyak 16 responden (16\%).

Sarana Pendukung Area parkir, hasil analisis diperoleh data berdasarkan karakteristik responden yang berpengaruh adalah jenis kelamin dan tingkat usia. 
Persentase berdasarkan jenis kelamin 54\% yang terdiri dari Jenis kelamin laki-laki memiliki persentase lebih dominan sebanyak 33 responden $(33 / 100 \times 100 \%=33 \%)$, perempuan sebanyak 21 responden (21\%), Persentase berdasarkan usia adalah 52\%. Usia rata-rata responden yakni 26-50 thn sebanyak 43 responden $43 \%$. Fasilitas Rekreasi Permainan Anak, dari hasil analisis diperoleh data berdasarkan karakteristik responden yang berpengaruh adalah jenis kelamin, tingkat pendidikan dan tingkat pendapatan. Persentase berdasarkan jenis kelamin adalah $34 \%$ terdiri dari jenis kelamin laki-laki sebanyak 21 responden $(21 / 100 \times 100 \%=21 \%)$, perempuan sebanyak 13 responden (13\%). Persentase berdasarkan tingkat pendidikan adalah $30 \%$. Tingkat pendidikan SMA dengan 14 responden (14\%). Persentase berdasarkan tingkat pendapatan adalah 29\%. Tingkat pendapatan diatas 2 juta lebih signifikan dengan jumlah responden sebanyak 11 responden (11\%). Sarana Pendukung Toilet umum, hasil analisis diperoleh data karakteristik responden yang berpengaruh adalah jenis kelamin, usia, tingkat pendidikan, jenis pekerjaan dan tingkat pendapatan. Persentase berdasarkan jenis kelamin adalah $53 \%$ terdiri dari jenis kelamin laki-laki memiliki persentase lebih dominan sebanyak 30 responden $(30 / 100 \times 100 \%=$ $30 \%$ ) dibandingkan dengan perempuan sebanyak 19 responden (19\%). Persentase berdasarkan tingkat pendapatan adalah $48 \%$. Tingkat pendapatan 1-2 juta lebih signifikan dengan jumlah responden sebanyak 12 responden (12\%). Persentase berdasarkan tingkat pendidikan adalah $47 \%$. Tingkat pendidikan SMA dengan 22 responden (22\%). Persentase berdasarkan usia adalah $46 \%$. Usia rata-rata responden yakni 26-50 thn sebanyak 32 responden $32 \%$. Persentase berdasarkan jenis pekerjaan adalah 46\%. Untuk profesi pekerjaan yang lebih dominan yakni pedagang sebanyak 17 responden (17\%).

Fasilitas Rekreasi Taman air, dari hasil analisis diperoleh data berdasarkan karakteristik responden yang berpengaruh adalah jenis kelamin dan tingkat pendidikan. Persentase berdasarkan jenis kelamin 50\% yang terdiri dari jenis kelamin laki-laki dengan 34 responden $(34 / 100 \times 100 \%=34 \%)$, perempuan sebanyak 16 responden $(16 \%)$,
Persentase berdasarkan tingkat pendidikan adalah 49\%. Tingkat pendidikan SMA dengan masing-masing 21 responden (21\%). Water Catchment Area Situ/Danau, dari hasil analisis diperoleh data berdasarkan karakteristik responden yang berpengaruh adalah jenis kelamin, tingkat usia dan pendapatan. Persentase berdasarkan jenis kelamin adalah $19 \%$. Jenis kelamin laki-laki memiliki persentase lebih dominan sebanyak 14 responden $(14 / 100 \times 100 \%=14 \%)$, perempuan sebanyak 5 responden (5\%). Persentase berdasarkan usia adalah $16 \%$. Usia rata-rata responden yakni 26-50 thn sebanyak 14 responden (14\%). Persentase berdasarkan tingkat pendapatan sebanyak $16 \%$. Tingkat pendapatan diatas 2 juta lebih signifikan dengan jumlah responden sebanyak 8 orang (8\%). Water Catchment Area Ruang Pemancingan, hasil analisis diperoleh data berdasarkan karakteristik responden yang berpengaruh adalah jenis kelamin dan tingkat pendidikan. Persentase berdasarkan jenis kelamin adalah $38 \%$, jenis kelamin laki-laki memiliki persentase lebih dominan sebanyak 27 responden $(27 / 100 \times 100 \%=27 \%)$ dibandingkan dengan perempuan sebanyak 11 responden (11\%). Persentase berdasarkan tingkat pendidikan sebanyak $38 \%$. Tingkat pendidikan SMA lebih dominan dengan 15 responden (15\%). Berdasarkan table data terlampir Karakteristik responden berdasarkan jenis kelamin, usia, dan tingkat pendidikan berpengaruh kuat terhadap kebutuhan fasilitas kawasan yang didominasi oleh kelompok responden masyarakat disekitar kawasan.

\section{Pembahasan}

Berdasarkan hasil penelitian yang telah dilakukan memberi gambaran bahwa karakteristik responden berdasarkan jenis kelamin, usia, dan tingkat pendidikan memiliki pengaruh kuat terhadap kebutuhan fasilitas rekreasi. Penelitian para ahli secara statistik menyebutkan perbedaan jenis kelamin antara laki-laki dan perempuan, baik dari segi motorik, kognitif, perilaku. Secara motorik lakilaki lebih mengembangkan kemampuan motorik kasar karena pengaruh hormon testosteron, ditambah minat dan dorongan budaya, jenis gerakan dan level aktivitas lebih tinggi daripada perempuan. Perbedaan kognitif laki-laki lebih inovatif dan kreatif dalam memecahkan masalah. Perbedaan 
perilaku laki-laki lebih banyak melakukan permainan fisik. Dalam pengambilan risiko, laki-laki lebih agresif (Murtiana, 2014). Tuntutan lingkungan juga mengakibatkan lakilaki lebih berani mengambil risiko. Perbedaan pergaulan hanya terbatas pada tingkat agresi antara laki-laki dan perempuan, anak laki-laki cenderung terlibat dalam permainan kasar dan berguling-guling seperti saling mendorong, menarik, memukul,mengejar, bergumul.

Fase usia dewasa awal merupakan kebutuhan untuk membuat komitmen dengan menciptakan suatu hubungan interpersonal yang erat dan stabil serta mampu mengaktualisasikan diri seutuhnya untuk mempertahankan hubungan tersebut. Ciri-ciri umum perkembangan fase usia dewasa awal yakni fase dewasa awal jika dikaitkan dengan usia pada fase ini menunjukkan bahwa peran, tugas dan tanggung jawab bukan hanya pencapaian keberhasilan akademik, melainkan mampu menunjukkan perilaku dan pribadi untuk mengeksplorasi berbagai gaya hidup dan nilai-nilai secara cerdas dan mandiri yang menunjukkan penyesuaian diri terhadap pola-pola kehidupan baru dan harapan sosial yang baru sebagai orang dewasa. Aspek-aspek perkembangan yang dihadapi usia dewasa awal adalah perkembangan sosio-emosional yang menggambarkan hubungan sosial individu dengan lingkungannya yang berdasarkan teori perkembangan. Masa remaja atau dewasa awal adalah masa saat terjadinya perubahanperubahan yang cepat termasuk perubahan fundamental dalam aspek kognitif, emosi, sosial dan pencapaian (Fagan, 2006). Fasefase masa remaja menurut Monks dkk (2004), dibatasi antara usia 12-21 tahun, dengan pembagian 12-15 tahun termasuk masa remaja awal, 15-18 tahun termasuk masa remaja pertengahan, 18-21 tahun termasuk masa remaja akhir.

Karakteristik yang menonjol pada anak usia sekolah menengah adalah kecenderungan ambivalensi antara keinginan menyendiri dengan keinginan bergaul dengan orang banyak serta antara keinginan untuk bebas dari dominasi dengan kebutuhan bimbingan dan bantuan dari orang tua. Beberapa karakteristik remaja yang dapat menimbulkan berbagai permasalahan pada diri remaja yaitu senang bereksperimentasi, senang bereksplorasi, mempunyai banyak fantasi, khayalan, dan bualan. Kecenderungan membentuk kelompok dan kecenderungan kegiatan berkelompok. Perkembangan fungsi aspekaspek fisik orang dewasa terus berjalan sesuai dengan jenis pekerjaan, pendidikan dan latihan serta hobi-hobi aktivitas fisik. Tingkat pendidikan SMA merupakan usia yang secara fisik sangat sehat, kuat, dan cekatan dengan tenaga yang cukup besar. Kekuatan dan kesehatan ini sangat dipengaruhi oleh kemampuan ekonomi, kebiasaan hidup, kebiasaan makan, dan pemeliharaan kesehatan. Kualitas kemampuan berpikirnya terus berkembang lebih meluas atau komprehensif dan mendalam. Perkembangan ini tergantung pada pengetahuan dan informasi yang dikuasai. Semakin tinggi dan luas ilmu pengetahuan, dan informasi yang dimiliki, semakin tinggi kualitas kemampuan berpikir (Latifah, 2010). Kemampuan kognitif terus berkembang selama masa SMA. Akan tetapi, bagaimanapun tidak semua perubahan kognitif pada masa SMA tersebut mengarah pada peningkatan potensi. Kadang-kadang beberapa kemampuan kognitif mengalami kemerosotan seiring dengan pertambahan usia. Meskipun demikian sejumlah ahli percaya bahwa kemunduran keterampilan kognitif yang terjadi terutama pada masa SMA akhir dapat ditingkatkan kembali melalui serangkaian pelatihan. Berbagai macam kebutuhan primer yang harus dipenuhi untuk mempertahankan hidup. Siswa SMA cenderung berkarakteristik sebagai berikut, secara fisik meningkatnya energi gerak pada setiap individu, selain ciri-ciri fisik terdapat pula beberapa ciri serta karakteristik lain dimiliki tingkatan SMA yaitu keinginan untuk menjelajah ke alam sekitar yang lebih luas, misalnya melibatkan diri dalam kegiatankegiatan pramuka, kelompok pecinta alam, dll. Aktivitas berkelompok tumbuh sedemikian besar. Sering mengkhayal dan berfantasi. Bentuk kreativitas yang akan terlihat sesudah orang dewasa akan tergantung pada minat dan kemampuan individual, kesempatan untuk mewujudkan keinginan dan kegiatankegiatan yang memberikan kepuasan sebesar-besarnya. Ada yang menyalurkan kreativitasnya ini melalui hobi, ada yang 
menyalurkannya melalui pekerjaan yang memungkinkan ekspresi kreativitas.

\section{Hasil Penelitian}

Berdasarkan data yang diperoleh hasil penelitian menyimpulkan bahwa 1) kondisi permukaan air tergenang dengan elevasi mencapai 6 meter dipermukaan air dengan luas area genangan $14,32 \mathrm{~km}^{2}$. Elevasi banjir besar mencapai 9 meter diatas muka air dengan luas genangan $195.00 \mathrm{~km}^{2}$. Kedalaman sungai 5 meter dalam kondisi normal. Ketersediaan fasilitas rekreasi belum memadai. 2) Kebutuhan jenis fasilitas berdasarkan karakteristik responden mencakup ruang terbuka hijau publik (RTH Publik), ruang terbuka hijau privat (RTH
Privat), fasilitas rekreasi, sarana pendukung, water catchment area, dan prasarana penunjang transportasi. 3) Arahan pengembangan adalah penambahan dan perbaikan fasilitas rekreasi baik dari segi kualitas dan kuantitasnya agar dapat meningkatkan ekonomi warga serta meningkatkan pendapatan asli daerah.

\section{Ucapan Terima kasih}

Ucapan terima kasih yang sebesarbesarnya atas segala atensi dan sumbangsi pemikiran kepada seluruh stakeholder yang ikut andil dalam penelitian ini. Semoga amal jariyah kita semua diterima Allah Subhana Wata'ala. Amin Yaa Rab'bal A'laamin.

\section{DAFTAR PUSTAKA}

Dinas Pemuda Olahraga Kebudayaan dan Parawisata Kabupaten Wajo. (2013). Data Pengunjung. Fagan. (2006). Teori Perkembangan.

Ginting S.W. (2004). Pengaruh Keberadaan Pedagang Kaki Lima Terhadap Jumlah Pengunjung Taman Kota di Medan.

Latifah M. (2010). Periode Remaja. Bogor. Departement of Family \& Consumer Sciences. Faculty of Human Biology Bogor Agriculture University.

Mirsa R. (2011). Elemen Tata Ruang Kota. Yogyakarta: Graha Ilmu.

Monks dkk. (2004). Fase-fase masa remaja.

Murtiana E. (2014). Perbedaan pria dan wanita secara psikologis.

Rahmawaty dkk. (2006). Karakteristik Pengunjung Rekreasi dan Obyek Wisata di Taman Hutan Raya DR. Mohammad Hatta.

Sujarto D. (2001). Pilihan Strategis Suatu Teknik Pengambilan Keputusan Dalam Perencanaan Wilayah dan Kota. Bandung: ITB. 